\title{
Review
}

\section{On ne naît pas femme: On le devient: The life of a sentence}

\author{
Bonnie Mann and Martina Ferrari (eds.) \\ Oxford University Press, Oxford, 2017, 362 pp., \\ ISBN: 9780190608811
}

Contemporary Political Theory (2019) 18, S121-S124. https://doi.org/10.1057/s41296018-0194-7; published online 23 January 2018

Yes, this book is based upon a single sentence: Beauvoir's renowned sentence: 'one is not born: one becomes (a) woman.' Yet it manages to spawn nineteen articles that cover multiple themes from numerous perspectives and disciplinary interests. Its four sections, Intellectual History; History of Scandal; the Philosopher's Debate; the Labor of Translation, include interventions on the sex/gender debates (Karen Offen, Judith Butler, Bonnie Mann, Meagan Burke), diverse philosophical interpretations of Beauvoir, as well as concrete and convincing demonstrations of how poorly translated passages promote misunderstandings (Toril Moi, Margaret Simons, Nancy Bauer). Since it is impossible to do justice to the breadth and wealth of this text in a short review, I have chosen to focus upon a few of the articles that I found particularly interesting. The brilliance of the collection lies in its interdisciplinary and meticulous analysis of this single sentence. Needless to say, its multiple interpretations don't fit together, but provide compelling arguments that can't be easily dismissed.

The new translation of The Second Sex in 2011 initiated a fervent debate amongst feminists. In dropping the article 'a' from Parshley's original English translation, Constance Borde and Sheila Malovany-Chevalier believed they were honoring Beauvoir's feminist legacy. They reasoned 'this best captures women as an institution, a construct, a concept; femininity determined and defined by society, culture and history' (p. 281). The presence of the 'a' stresses the existential tradition that one is free to choose irrespective of one's situation.

Bonnie Mann's 'Beauvoir against Objectivism' provides an excellent introduction to the volume by offering a concise summary of Beauvoir's philosophic concerns, which furthers the project of thinking philosophically about the tensions arising from the translation of this sentence. Unlike Butler, whose discursive theory swings towards objectivism, Beauvoir's notion of embodied engagement avoids subjectivism and rationalism, without lapsing into objectivism or materialism. Mann brings Butler's performative theory of gender into conversation with

(c) 2018 Macmillan Publishers Ltd., part of Springer Nature. 1470-8914 Contemporary Political Theory Vol. 18, S2, S121-S124 www.palgrave.com/journals 
Beauvoir's existential treatment. While Butler analyzes how norms operate to include and exclude, 'another dimension of Beauvoir's analysis drops out, leaving us with a narrower, less politically able account' (p. 46). Mann rightly notes 'this leaves the impression that oppression is undone and equality is won through the revelation of the performative nature of gender, while the entire material apparatus of domination and subordination that is secured by the norm remains intact' (p. 49).

As a social historian, Karen Offen's archival work challenges the idea that the sex/gender distinction is Anglo-American in origin. While French feminists have preferred to use the terms (masculin/féminin or la différence sexuelle) and stubbornly resisted the sex/gender distinction as well as the term 'genre' to designate socially constructed differences, Offen offers evidence that early modern French thinkers used the term 'genre' to highlight the social constitution of gender. Her point is not to claim the French were the source of the distinction, but rather to show how tracing historical usage shows that the fluidity of gender has a long history in France, contrary to the opinion of some. To dismiss the sex/gender distinction as Cartesian, as Rosi Braidotti has done, or gender as a neologism, is shortsighted. She warns theorists to be apprised of socio/historical and cultural complexity: 'being born a woman is very different in different countries,' and to give the term meaning, theorists must consult anthropologists, sociologists, as well as historians. In the process, she takes a jab at Butler and Braidotti for having evacuated the physical maternal body by seeing the materiality of the body as a linguistic construction.

In 'The Floating "a"' Debra Bergoffen shores up the new translation, though not unqualifiedly. It is praised for drawing our attention to Beauvoir's materialist sensibility: 'her analysis of the ways that social practices produce material realities that are then ideologically naturalized' (p. 143). Nevertheless, this reading occludes the singular experience of birth and how we live our human body in historical and unpredictable ways (p. 144). In erasing the ' $a$ ' one gives too much power to the myth/concept/determinations women are subject to, thereby denying women's desire for freedom and the affirmation of subjectivity, yet the assertion of the ' $a$ ' tends to ignore how existing social relations impede women's freedom. Bergoffen proposes the excellent idea of floating the 'a,' citing Kristeva, who had spent most of her life vilifying Beauvoir as male identified, but who, after Beauvoir's death, came to appreciate her approach to singularity. Bergoffen rightly identifies the tension: "Whether we decide for or against the "a" may depend upon the extent we accept Beauvoir's conviction that, as historical beings, we are both constrained by the concrete conditions of our life, and we are also necessarily the embodiment of a desire for freedom' (p. 157).

Burke refuses to accept that the 2011 translators committed an error: rather, they made an 'informed decision' to read Beauvoir as a social constructionist and not as a phenomenologist. Beginning with Butler's social constructivism and her reading of Beauvoir, Burke argues that the significance of the sex/gender distinction is 
overplayed. In the process, Butler instantiates her own approach to sex as gendered, yet wrongly attributes to Beauvoir a stable, factive body as the foundation of human existence and sexed differences. Beauvoir is not an essentialist, but maintains a socially constructed position, one informed by phenomenology rather than poststructuralism. While Beauvoir admits there are sexed differences (i.e., women have weaker bodies, much to the chagrin of some feminists), our bodies are always enveloped in a worldly situation. The body does not exist outside our social or cultural relations as the grounds for gender, but the living body involves the entanglement of both biology, culture, as well as social circumstances. Thus, Beauvoir appreciates the singularity of existence 'how one lives gender as a woman, in a given time and place' (p. 172). Burke rejects the sex/gender distinction, but on different grounds than Butler and Braidotti.

The sections on translation explore the specific challenges faced by Spanish (López Sácenz), German (Baumeister), Finnish (Ruonakoski), and Serbo-Croat (Bogiç) translators, as well as offer glimpses into the politics of the translation. Although we know intuitively how important translation is, Simons, Bauer, and Moi's concrete comparisons and parsing of passages between the Borde and Malovany-Chevalier, Parshley and original texts, provides irrefutable evidence as to how meanings get misconstrued. The first section on translation - History of a Scandal - traces the history of the first translation of The Second Sex. Margaret Simon's 1983 article is reprinted. Noting that $10 \%$ of the original text was deleted (specifically passages on the history of women's movements, entries acknowledging women writers and exceptional women), Simons rightly points to Parshley's sexism. Since most references to socialism and socialist feminism were excised from his 1951 translation, I would also add, his anticommunist sentiments are also evidenced. Perhaps more troubling is Parshley's failure to appreciate Beauvoir's philosophic language, hardly surprising since he was a zoologist. In translating existential and specifically Heideggerian concepts like human reality, Dasein, as the human condition of man, he misconstrues its meaning. Building upon Simon's and Fallaize's scrupulous comparisons of the original and translated meanings in the late 90s Toril Moi brilliantly produces even more reasons and examples as to why a re-translation was in order. Her meticulous readings reveal not only bungled philosophic meanings (hiding Hegel, mistranslating Marx's concept of alienation) but serious deletions that altered the tone of Beauvoir's text. Omitting women's voices from the section on women's lived experience and removing examples of exceptional women, Parshley fueled the now common perception that Beauvoir is male-identified and not interested in women. Moi attributes Drucilla Cornell's essentializing Beauvoir's anti-maternalist stance to Parhsley's omissions and botched translation. Moi also shares her appeal to Vintage/Knopf for a new translation (cataloguing errors and serious omissions) and their churlish response.

To the new (Borde and Malovany-Chevalier) translation, Moi and Bauer respond disapprovingly, whereas Simons and Altman are more forgiving of its errors. Sadly,

(c) 2018 Macmillan Publishers Ltd., part of Springer Nature. 1470-8914 Contemporary Political Theory Vol. 18, S2, S121-S124 S123 
an annotated edition was not produced, which would have helped readers make sense of Beauvoir's referents, often local and idiosyncratic; nor was an accomplished translator (from French to English) selected. Again, errors in translation were recorded by scholars in 2010, and corrections were made in the next edition. In preserving the original structure and literalness of meaning, Borde and Malovany-Chevalier, 'sacrifice readability and clarity in favor of a highly unidiomatic word-by-word literalism that hampers the flow of the Beauvoir's prose and often obfuscates it meaning' (Bauer, p. 116). In contrast, Altman supports the 2011 translation as reliable. 'The slight estrangement induced by the text' (p. 134), she argues, is preferable to Parshley's translation, which domesticated the foreignness to please the American audience.

All the pieces in this volume thus offer unique readings of this sentence and Beauvoir's philosophic project more generally, attesting to the significance of translation, as well as providing thoughtful interventions in feminist theory, past and present. This is a must-read for those interested in Beauvoir's ideas, in translation, as well as in a critical engagement with the various turns in feminist theory. 